\title{
국내 두 폐금속 광산의 중금속오염 인체위해성평가 비교 Comparative Study on the Human Risk Assessment of Heavy Metal Contamination between Two Abandoned Metal Mines in Korea
}

\author{
임태용 · 이상우 · 박미정* · 이상환* 김순오 \\ Tae-Yong Lim $\cdot$ Sang-Woo Lee $\cdot$ Mi Jeong Park* $*$ Sang-Hwan Lee* ${ }^{*}$ Soon-Oh Kim ${ }^{\dagger}$ \\ 경상대학교 지질과학과 및 기초과학연구소 **한국광해관리공단 광해기술연구소 \\ Department of Geology and Research Institute of Natural Science (RINS), Gyeongsang National University (GNU) \\ *Institute of Mine Reclamation Technology, Mine Reclamation Corporation (MIRECO)
}

(Received November 3, 2015; Revised November 26, 2015; Accepted November 30, 2015)

\begin{abstract}
This study was conducted to propose the methodology of human risk assessment specialized to domestic mine areas and to quantify the human risk of heavy metal ( $\mathrm{As}, \mathrm{Cd}, \mathrm{Cu}, \mathrm{Pb}$, and $\mathrm{Zn}$ ) contamination around two abandoned metal mines. To attain the goals, we established a relevant exposure scenario, including 7 exposure pathways and extracted a variety of exposure factors reflecting the characteristics of inhabitants around abandoned metal mine areas. Finally, carcinogenic and non-carcinogenic risks were compared between two areas, exposure pathways, heavy metal contaminants, and receptors. The total excess carcinogenic risks of two mine areas of concern were calculated to be larger than the acceptable carcinogenic risk $\left(1 \times 10^{-6}\right)$, indicating those two areas are not safe for carcinogenic hazard. In addition, the hazard indices of two areas were computed to be higher than unit risk (1), suggesting that the areas of concern have non-carcinogenic risk. Ingestion of crop and intake of groundwater were evaluated to be main exposure pathways contributing to carcinogenic and non-carcinogenic risks within the areas. Also, the results show that carcinogenic and non-carcinogenic hazards were mostly attributed to $\mathrm{As}$ and $\mathrm{As}, \mathrm{Cd}$, and $\mathrm{Pb}$, respectively.
\end{abstract}

Key Words : Human Risk Assessment, Abandoned Metal Mines, Heavy Metal Contamination, Carcinogenic Risk, Non-carcinogenic Risk

\begin{abstract}
요약 : 본 연구는 국내 폐금속 광산에 특화된 인체위해성평가 방법을 제시하고, 두 폐금속 광산 지역에 시범적으로 적용하 여 광산별 중금속 오염물질 $(\mathrm{As}, \mathrm{Cd}, \mathrm{Cu}, \mathrm{Pb}, \mathrm{Zn})$ 에 대한 인체위해도를 정량적으로 산출하고자 수행되었다. 이를 위해 폐금속 광산에 적합한 7 가지 노출경로 등의 노출시나리오를 설정하고, 폐금속 광산 지역 거주 주민의 특성에 맞는 노출인자를 추출 하여 인체위해성평가에 활용하였다. 또한 최종적으로 얻어진 발암 및 비발암 위해특성을 광산별, 노출경로별, 오염물질별, 수용체별로 비교 분석하였다. 두 광산 모두에서 총 초과발암위해도가 허용 가능한 위해도인 $1 \times 10^{-6}$ 의 값보다 크게 나타나서 발암위해성이 있는 것으로 판명되었으며, 두 광산에서의 발암위해성은 유사한 것으로 조사되었다. 뜨한 두 광산 모두에서 성 인에 대한 위험지수가 1 보다 큰 값을 보여 비발암위해성이 있는 것으로 나타났고, 어린이의 경우에는 위험지수가 1 보다 작 은 값을 보여 상대적으로 비발암위해성이 낮은 것으로 조사되었다. 비발암위해성은 대정광산에서 봉광산보다 상대적으로 큰 것으로 나타났다. 그리고 발암 및 비발암위해성을 유발하는 주요한 노출경로는 농작물섭취와 지하수섭취로 평가되었다. 어 린이의 경우에는 성인에 비해 상대적으로 표토섭취와 표토피부접촉 경로에 의한 발암 및 비발암 위해성이 큰 것으로 조사되 었다. 오염물질별 위해성을 살펴보면, 발암위해성은 $\mathrm{As}$, 비발암위해성은 $\mathrm{As}, \mathrm{Cd}, \mathrm{Pb}$ 등으로부터 주로 유발되어 $\mathrm{As}$ 가 발암 및 비발위해성의 주요한 오염물질로 조사되었다.
\end{abstract}

주제어 : 인체위해성평가, 폐금속 광산, 중금속오염, 발암위해도, 비발암위해도

\section{1. 서 론}

현재, 국내에는 많은 휴·폐 광산이 존재하고 있으며, 그 중 다수의 광산들이 적절한 환경오염 방지시설 없이 방치 되어 있는 실정이다. ${ }^{1} 1990$ 년대 중반 이후로 광산지역의 중금속 오염물질에 의한 환경오염 문제가 제기되면서 이에 대한 복원 및 관리가 주요한 관심사로 대두되어 오고 있다. ${ }^{2}$

휴-폐 금속광산에 존재하는 폐석 및 광미들은 다양한 유 해 금속 및 비금속 성분들을 고농도로 함유하고 있으며, 적 절한 환경오염 방지시설 없이 방치된 이러한 폐석 및 광미 로부터 중금속 오염물질들이 유출되어 주변 환경 및 생태 계에 악영향을 미쳐오고 있다. 특히, 강우나 강풍에 의해
중금속 오염물질을 고농도로 함유한 폐석 및 광미들이 주 변 지표수, 지하수 및 토양으로 유출되어 농작물에 전이됨 으로써 인근 거주 주민들의 인체 건강에 심각한 위해를 초 래하고 있다. ${ }^{1,3}$

미국 등 선진국에서는 오래전부터 환경오염이 인체에 미 치는 부정적인 영향을 정량적으로 평가하기 위한 시도와 연구들이 활발히 진행되어 다양한 위해성 평가 기법과 프로 그램이 개발되었다. ${ }^{4-8)}$ 그러나 우리나라의 경우 1990년대 중반부터 오염토양의 위해성평가에 대한 중요성을 인식하 고, 위해성평가에 포함되어 있는 세부적인 변수에 대한 연 구를 시작하였고, 2006년에 들어 환경부 토양오염 위해성 평가지침을 제정하여 인체위해성평가를 위한 법적 기반이 
마련되었다. ${ }^{9)}$ 하지만 이러한 지침을 준용한 위해성평가는 아직까지 활발하게 이루어지지 않고 있는 실정이다.

특히, 오염된 토양의 인체위해성평가를 위해서는 대상 지 역의 환경 및 실정을 고려한 노출경로 설정과 더불어 그에 적합한 노출인자들이 사용되어야 한다. 하지만 국내에서는 아직까지 수용체, 환경매질, 오염물질 각각의 특성을 반영 한 노출인자들에 대한 설정이 미비되어 국외에서 활용되어 진 값들을 이용하여 인체위해성평가가 이루어져 왔다. 이 로 인하여 최종적으로 획득된 위해도에 대한 신뢰성을 확보 하는데 어려움이 있어 왔다.

따라서 본 연구는 국내 폐금속 광산에 특화된 인체위해 성평가 모델을 마련하고자 수행되었다. 이를 위해 폐금속 광산에 적합한 노출경로 등의 노출시나리오를 설정하고, 폐 금속 광산 지역 거주 주민의 특성에 맞는 노출인자를 추출 하여 인체위해성평가를 수행하였다. 또한 이렇게 마련된 인 체위해성평가 모델을 두 폐금속 광산 지역에 적용하여 광 산별 중금속 오염토양의 인체위해도를 정량적으로 산출하 고, 각 광산별 위해도를 노출경로별, 오염물질별, 수용체별 로 비교하여 평가하였다.

\section{2. 연구방법}

\section{1. 연구지역}

본 연구에서는 두 개의 폐금속 광산을 대상으로 인체위해 성평가를 수행하였다. 첫 번째 연구대상 광산인 봉(봉산)광 산은 1994년에 폐광되었으며 경상남도 합천군 봉산면 술곡 리에 위치하고 있다. 8 개의 갱구에서 광산 활동이 이루어졌 으며, 주요광종은 금, 은, 구리, 납, 아연이다. 봉(봉산)광산 지역의 주요한 지질은 시대미상의 편마암상 화강암과 선캄 브리아기 편마암으로 구성되며, 백악기 후기에 염기성 암맥 이 이들을 관입하고 있다. 광상은 편마암상 화강암 내에 발 달하는 열극을 충진한 함금은 석영맥으로 이루어져 있다. ${ }^{10,11)}$ 이 광산은 1926년에서 1931년까지 금 $41 \mathrm{~kg}$ 과 $\mathrm{Au}, \mathrm{Ag}$ 광 석 372 톤을 채광하였고, 1943년에서 1945년까지는 Au 45 $\mathrm{kg}, \mathrm{Cu}$ 64톤을 생산하였으며, 1981년에는 $\mathrm{Au}, \mathrm{Ag}, \mathrm{Cu}$ 리 총 $3 \mathrm{~kg}, 1982$ 년에서 1994년까지는 Au $140 \mathrm{~g}, \mathrm{Ag} 4 \mathrm{~g}$ 을 생산 하였다. ${ }^{10,11)}$

다른 연구대상 광산은 대정(대장)광산으로 경상남도 진주 시 지수면 청원리에 위치하고 있으며, 1992년에 폐광되었 다. 이 지역에는 13 개의 갱구가 발견되며, 주요한 광종은 상기한 봉(봉산)광산과 동일한 금, 은, 구리, 납, 아연이다. 대정(대장)광산 일대 주요 지질은 백악기 경상누층군의 함 안층 및 후기에 이를 관입한 불국사 화강암류인 진동화강 암(화강섬록암)으로 구성되며, 광상은 함안층 및 화강섬록암 내의 열극을 충진한 함금은 석영맥으로 발달되어 있다. ${ }^{10,11)}$ 이 광산에서는 1967년에서 1968년까지 Au $197 \mathrm{~g}, \mathrm{Ag} 24$ $\mathrm{kg}, \mathrm{Cu} 5,935 \mathrm{~kg}$ 을, 1984년에는 Au $190 \mathrm{~g}, \mathrm{Ag} 104 \mathrm{~kg}$ 을 생 산하였다. ${ }^{10,11)}$
이 두 광산을 연구대상 지역으로 선정한 이유는, 이 두 광 산은 대표적인 비철금속 및 귀금속광상으로서 유해 중금속 을 포함한 황화광물이 다량 존재함으로써 광산 활동으로 인한 주변 환경에 대한 중금속 오염 잠재성이 높기 때문이 었다. 이러한 중금속 오염에 대한 우려 때문에 환경부에서 수행한 폐금속 광산 환경오염실태조사에서 조사대상 광산 으로 선정되어 조사가 이루어진 바 있다. ${ }^{10,11)}$

\section{2. 시료 채취 및 분석}

\subsection{1. 토양시료 채취 및 분석}

봉(봉산)광산 184 개, 대정광산 252 개 표토시료를 폴리에 틸렌 용기에 채취하였다. 광산으로부터 하류방향으로 인접 한 농경지를 위주로 표토를 채취하였다. 표토시료 내 중금 속 함량 측정을 위해 채취한 토양시료를 풍건시킨 후 100 mesh $(0.15 \mathrm{~mm})$ 의 표준체로 체거름 하였다. 체거름 한 건조 토양시료 $3 \mathrm{~g}$ 과 질산용액 $7 \mathrm{~mL}$, 염산용액 $21 \mathrm{~mL}$ 을 혼합하 여 온도를 서서히 올려 환류조건에 도달하도록 하고 2시간 동안 추출과정을 거쳤다. 분해가 완료된 후에 추출액에 적당 량의 증류수를 첨가하여 7,000 rpm으로 원심 분리하여 상등 액을 $0.45 \mu \mathrm{m}$ 실린지 필터로 여과하여 분석용 시료용액을 제 조하였다. 그리고 유도결합플라스마분광기(ICP-OES, 4300, $5300 \mathrm{DV}$, Perkin Elmer, USA)를 이용하여 대상 중금속의 총 함량을 분석하였다.

\subsection{2. 수질시료 채취 및 분석}

본 연구지역에서 지하수(봉산광산 6개, 대정광산 6개) 및 지표수(봉산광산 5 개, 대정광산 5 개) 시료는 현장에서 0.45 $\mu \mathrm{m}$ 필터를 이용하여 부유물질을 제거하고 농질산 $\left(\mathrm{HNO}_{3}\right)$ 을 첨가하여 채수병에 채취하였다. 지표수 및 지하수의 인체위 해성평가를 위하여 토양시료와 동일하게 유도결합플라스마 분광기(ICP-OES, 4300, 5300DV, Perkin Elmer, USA)를 이 용하여 대상 중금속의 총 함량을 분석하였다.

\section{3. 인체위해성평가 수행방법}

일반적으로 인체위해성평가는 유해성 확인(hazard identification), 노출평가(exposure assessment), 용량-반응 평가(doseresponse assessment) 또는 독성 평가(toxicity assessment), 위 해도 결정(risk characterization)의 4단계로 수행된다.

\subsection{1. 유해성 확인}

1단계 유해성확인(hazard identification)은 평가대상 부지, 본 연구에서는 폐금속 광산 지역 내 오염물질의 존재여부 와 오염물질 종류, 존재하는 오염물질의 유해성을 확인하는 단계이다. 본 연구에서는 위해성평가 대상오염물질로 $\mathrm{As}$, $\mathrm{Cd}, \mathrm{Cu}, \mathrm{Pb}, \mathrm{Zn}$ 을 선정하였다. 이러한 5 종의 중금속 오염 물질을 선정한 이유는 크게 세 가지였다. 첫째로 이러한 5 종의 중금속은 국내 폐금속 광산 지역에서 가장 빈도가 높 게 나타나는 오염물질이기 때문이었다. 두 번째 이유로는 
이러한 오염물질들이 본 연구의 위해성평가 대상인 두 폐 금속 광산 지역에서 공통으로 존재하는 오염물질이었다. 마 지막으로 다른 중금속 오염물질에 비해 인체위해성평가를 위한 독성자료가 비교적 풍부하다는 것이었다.

\subsection{2. 노출평가}

본 연구에서 고려한 폐금속 광산 지역 중금속 오염에 대 한 인체위해성평가를 위한 노출시나리오를 Fig. 1에 요약하 였다. 폐금속 광산 지역의 주요한 오염원으로 광미, 폐석, 갱내수, 침출수 등을 고려하였으며, 이러한 오염원들로부터 표토, 지하수, 지표수, 농작물, 실외공기 등의 매체를 통하 여 오염물질이 주변 환경으로 전이되는 것으로 노출시나리 오를 산정하였다. 또한 인체로 오염물질이 유입되는 주요한 노출경로로서 표토섭취, 표토피부접촉, 표토호흡(비산), 지 하수섭취, 지표수피부접촉, 농작물섭취, 실외공기호흡(휘발) 등의 7 가지를 고려하였다. 마지막 노출경로인 휘발에 의 한 실외공기호흡 경로는 수은과 같이 휘발성이 큰 중금속 오염물질이 포함된 경우에 고려할 수 있는데, 본 연구에서 는 휘발성이 없는 5 종의 중금속 오염물질을 대상으로 하였 기 때문에 마지막 노출경로는 고려하지 않았다. 그리고 오 염물질에 노출되는 수용체는 크게 어린이와 성인, 성인의 경우에는 남성과 여성, 그리고 거주자와 작업자로 구분하였 다. 본 연구에서는 광산지역 거주자를 대상으로 하였고, 성 인 남성과 여성, 그리고 어린이 등의 세 종류의 수용체를 평 가 대상으로 고려하였다.

먼저 각 노출경로별 인체 노출량, 즉 일일 평균 노출량 (average daily dose, $\mathrm{ADD}$ )은 각 환경매체별 시료로부터 측 정된 중금속 오염물질의 농도로부터 산정한 노출농도와 Table 1에 주어진 식들을 이용하여 계산하였다. Table 1의 노 출량 산정식들에 포함된 다양한 노출인자들은 각 인자들이 나타내는 특성을 반영하여 수용체 인자(Table 2), 오염물질 인자(Table 3), 그리고 환경매질 인자(Table 4) 등으로 구분 하여 여러 자료들을 이용하여 획득한 후 정리하였다. 특히 수용체 인자는 평가대상 지역 거주민들의 특성을 잘 반영 한 값들이 이용되어야 인체위해성평가의 신뢰성을 확보할 수 있지만, 지금까지 수행된 대부분의 인체위해성평가들에
Table 1. Equations for calculating the average daily dose of each exposure pathway

\begin{tabular}{|c|c|c|}
\hline Media & $\begin{array}{l}\text { Exposure } \\
\text { pathway }\end{array}$ & Equation for average daily dose* \\
\hline \multirow{4}{*}{$\begin{array}{l}\text { Surface } \\
\text { soil }\end{array}$} & \multirow{2}{*}{$\begin{array}{l}\text { (1) Oral } \\
\text { (mg/kg-day) }\end{array}$} & $C_{s} \times C R_{s} \times C F_{1} \times A B S_{G I} \times E F \times E D$ \\
\hline & & \\
\hline & $\begin{array}{l}\text { (2) Dermal } \\
\text { (mg/kg-day) }\end{array}$ & $\frac{C_{s} \times\left(A F \times A B S_{D} \times C F_{1}\right) \times S A e \times E F \times E D}{B W \times A T}$ \\
\hline & $\begin{array}{l}\text { (3) Inhalation } \\
\text { (suspended } \\
\text { soil) }\left(\mathrm{mg} / \mathrm{m}^{3} \text { ) }\right.\end{array}$ & $\frac{C_{s} \times A B S_{i n h} \times(T S P \times f r s \times F r) \times E F \times E D \times C F_{1}}{A T}$ \\
\hline
\end{tabular}

Ground (4) Oral
water $(\mathrm{mg} / \mathrm{kg}$-day) $\frac{C_{w} \times C R_{w} \times E F \times E D}{B W \times A T}$

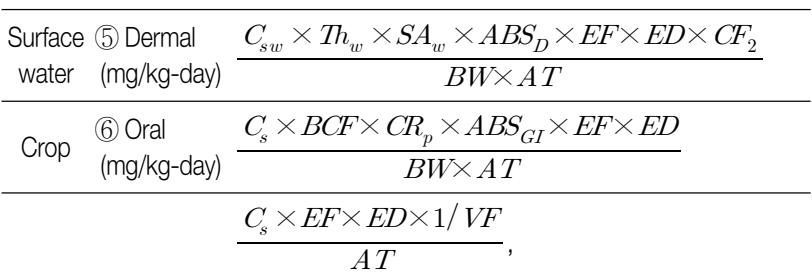

Outdoo (7) Inhalation where,

rair $\begin{aligned} & \text { (volatilization) } \\ & \left(\mathrm{mg} / \mathrm{m}^{3}\right)\end{aligned} \quad V F=\frac{Q / C_{\text {vol }} \times \sqrt{\left(3.14 \times D_{A} \times T\right)} \times 10^{-4}\left(\mathrm{~m}^{2} / \mathrm{cm}^{2}\right)}{2 \times \rho_{b} \times D_{A}}$

$$
, D_{A}=\frac{\left(\theta_{a}^{10 / 3} \times D_{i} \times H+\theta_{w}^{10 / 3} \times D_{w}\right) / n^{2}}{\left(\rho_{b} \times K_{d}+\theta_{w}+\theta_{a} \times H\right)}
$$

${ }^{\star} \mathrm{C}_{\mathrm{s}}$ : Exposure conc. of surface soil $(\mathrm{mg} / \mathrm{kg})$;

$\mathrm{C}_{\mathrm{w}}$ : Exposure conc. of groundwater $(\mathrm{mg} / \mathrm{L})$;

$\mathrm{C}_{\text {sw: }}$ : Exposure conc. of surface water (mg/L);

$\mathrm{C}_{\mathrm{p}}$ : Exposure conc. of crop $(\mathrm{mg} / \mathrm{kg})$; The other parameters in the equations are given in Table 2 4

서는 국외 자료 또는 우리나라 전체 인구에 대한 통계값을 이용하였다. 따라서 본 연구에서는 우리나라 폐금속 광산 지 역 주변에 거주하는 주민들의 특성을 반영한 수용체 인자 를 추출하기 위하여 국립환경과학원에서 2007년에서 2011 년까지 5년간 수행한 폐금속 광산 주민건강영향조사 결과 를 활용하였다. ${ }^{12 ~ 16)}$ 성인남성 2,834 명, 성인여성 4,248명, 그리고 어린이 285 명을 대상으로 하여 체중, 신장, 노출기간, 평균시간 등을 획득하였다(Table 2). 먼저 체중(body weight, $\mathrm{BD})$ 의 경우 국내 오염토양 위해성평가지침에서는 한국 노

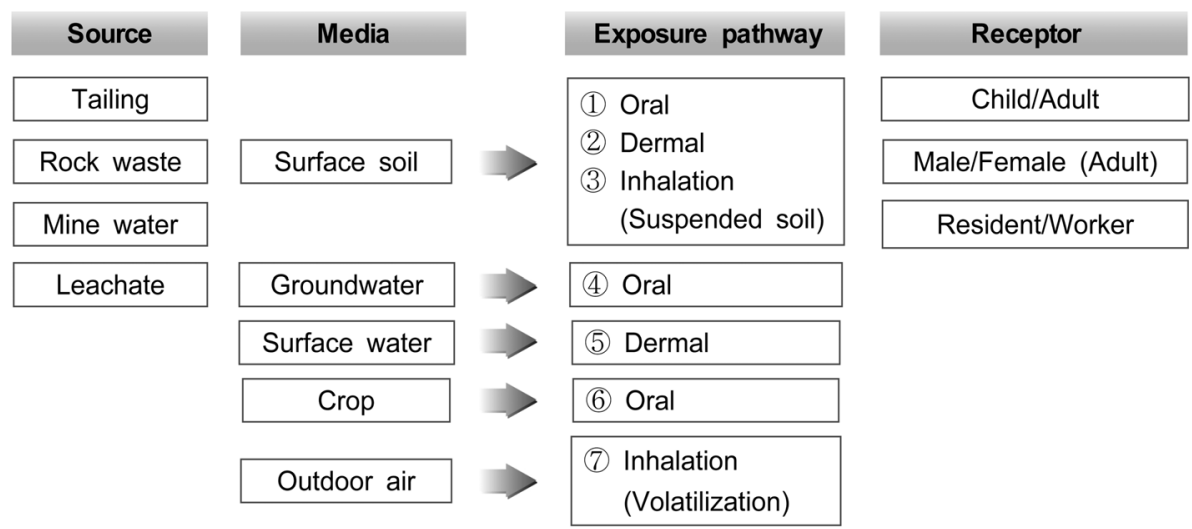

Fig. 1. Exposure scenario for human risk assessment of heavy metal contamination in abandoned mining areas. 
Table 2. Exposure factors specified for residents around abandoned metal mine area

\begin{tabular}{|c|c|c|c|c|c|c|}
\hline \multirow[b]{2}{*}{ Parameter } & \multirow{2}{*}{$\begin{array}{c}\text { Abbrevi- } \\
\text { ation in } \\
\text { Table } 1\end{array}$} & \multirow[b]{2}{*}{ Unit } & \multicolumn{3}{|c|}{ Value } & \multirow[b]{2}{*}{$\begin{aligned} &- \text { Refer- } \\
& \text { ence }\end{aligned}$} \\
\hline & & & $\begin{array}{l}\text { Adult } \\
\text { male }\end{array}$ & $\begin{array}{l}\text { Adult } \\
\text { female }\end{array}$ & Child & \\
\hline Body weight & BW & $\mathrm{kg}$ & 59.9 & 57.7 & 36.0 & $12 \sim 16$ \\
\hline Exposure duration & ED & years & 48.4 & 41.9 & 8.2 & $12 \sim 16$ \\
\hline Average time & AT & days & 28,656 & 31,047 & 29,908 & 17 \\
\hline Exposure frequency & EF & $\begin{array}{l}\text { days/ } \\
\text { year }\end{array}$ & 350 & 350 & 350 & 18 \\
\hline $\begin{array}{l}\text { Surface area of body for } \\
\text { dermal contact of soil }\end{array}$ & $S A_{e}$ & $\begin{array}{l}\mathrm{cm}^{2} / \\
\text { day }\end{array}$ & 4,212 & 3,903 & 2,978 & $\begin{array}{c}12 \sim \\
16,19\end{array}$ \\
\hline $\begin{array}{l}\text { Surface area of body for } \\
\text { dermal contact of water }\end{array}$ & $\mathrm{SA}_{\mathrm{w}}$ & $\begin{array}{l}\mathrm{cm}^{2} / \\
\text { day }\end{array}$ & 23,000 & 21,312 & 16,261 & 20,21 \\
\hline $\begin{array}{l}\text { Soil-skin adsorption co- } \\
\text { efficient }\end{array}$ & AF & $\begin{array}{l}\mathrm{mg} / \\
\mathrm{cm}^{2}\end{array}$ & 0.07 & 0.07 & 0.20 & 22 \\
\hline $\begin{array}{l}\text { Water-skin adsorption } \\
\text { thickness }\end{array}$ & $\mathrm{Th}_{\mathrm{w}}$ & $\mathrm{cm}$ & & 2.34E-03 & & 22 \\
\hline $\begin{array}{l}\text { Retention of soil particles } \\
\text { in lung }\end{array}$ & $\mathrm{Fr}$ & - & & 0.75 & & 6 \\
\hline Intake rate of soil & $\mathrm{CR}_{\mathrm{s}}$ & $\mathrm{mg} /$ day & 50 & 50 & 118 & 20 \\
\hline $\begin{array}{l}\text { Intake rate of ground- } \\
\text { water }\end{array}$ & $\mathrm{CR}_{w}$ & L/day & 1.66 & 1.35 & 1.00 & 20 \\
\hline Intake rate of crop (cereal) & ) $\mathrm{CR}_{\mathrm{p}}$ & $\mathrm{kg} /$ day & 0.440 & 0.386 & 0.336 & 20 \\
\hline
\end{tabular}

Table 3. Exposure factors related to the properties of heavy metal contaminants

\begin{tabular}{|c|c|c|c|c|c|c|c|c|}
\hline \multirow{2}{*}{ Parameter } & \multirow{2}{*}{\multicolumn{2}{|c|}{$\begin{array}{l}\text { Abbrevi } \\
\text { ation in Unit } \\
\text { Table } 1\end{array}$}} & \multicolumn{5}{|c|}{ Value } & \multirow{2}{*}{$\begin{array}{r}\text { Refer- } \\
\text { ence }\end{array}$} \\
\hline & & & As & Cd & $\mathrm{Cu}$ & $\mathrm{Pb}$ & $\mathrm{Zn}$ & \\
\hline $\begin{array}{l}\text { Gastrointestinal ab- } \\
\text { sorption coefficient }\end{array}$ & $\mathrm{ABS}_{\mathrm{Gl}}$ & - & 0.950 & 0.025 & 0.570 & $N D$ & ND & 25 \\
\hline $\begin{array}{l}\text { Dermal absorption } \\
\text { coefficient }\end{array}$ & $A B S_{D}$ & - & 0.030 & 0.140 & 0.100 & 0.006 & 0.020 & 26 \\
\hline $\begin{array}{l}\text { Inhalation absorption } \\
\text { coefficient }\end{array}$ & ABS ihh & - & 1.000 & 1.000 & 1.000 & 1.000 & 1.000 & 6 \\
\hline $\begin{array}{l}\text { Soil-crop bio-con- } \\
\text { centration factor }\end{array}$ & BCF & - & 0.029 & 0.081 & ND & 0.007 & 0.100 & 27,28 \\
\hline \multicolumn{9}{|c|}{$\mathrm{ND}=$ not determined } \\
\hline \multicolumn{9}{|c|}{$\begin{array}{l}\text { Table 4. Exposure factors related to the properties of environ- } \\
\text { mental media and conversion factors }\end{array}$} \\
\hline \multicolumn{2}{|l|}{ Parameter } & \multicolumn{2}{|c|}{$\begin{array}{l}\text { Abbreviation } \\
\text { in Table } 1\end{array}$} & \multicolumn{2}{|l|}{ Unit } & Value & \multicolumn{2}{|c|}{ Reference } \\
\hline \multicolumn{2}{|c|}{$\begin{array}{l}\text { Amount of suspended } \\
\text { particles in air }\end{array}$} & \multicolumn{2}{|c|}{ TSP } & \multicolumn{2}{|c|}{$\mathrm{mg} / \mathrm{m}^{3}$} & 0.07 & \multicolumn{2}{|r|}{6} \\
\hline \multicolumn{2}{|c|}{$\begin{array}{l}\text { Fraction of soil in sus- } \\
\text { pended particles in air }\end{array}$} & \multicolumn{2}{|c|}{ frs } & - & & 0.50 & \multicolumn{2}{|r|}{6} \\
\hline \multicolumn{2}{|c|}{ Conversion factor 1} & \multicolumn{2}{|c|}{$\mathrm{CF}_{1}$} & $\mathrm{~kg} / \mathrm{ms}$ & & 00E-06 & & - \\
\hline \multicolumn{2}{|c|}{ Conversion factor 2} & \multicolumn{2}{|c|}{$\mathrm{CF}_{2}$} & $\mathrm{~L} / \mathrm{m}^{3}$ & & $00 \mathrm{E}+03$ & & - \\
\hline
\end{tabular}

출계수 핸드북 $(\mathrm{ME})^{20)}$ 의 값인 성인 $62.8 \mathrm{~kg}$, 어린이 $16.8 \mathrm{~kg}$ 을 제시하고 있다. 본 연구에서 사용한 수용체의 체중은 폐 금속 광산 주민건강영향조사의 자료를 바탕으로 통계처리 한 후에 얻어진 평균 체중인 성인남성 $59.9 \mathrm{~kg}$, 성인여성 57.7 $\mathrm{kg}$, 그리고 어린이 $36.0 \mathrm{~kg}$ 값을 이용하였다. 또한 노출기간 (exposure duration, ED)은 일생을 통해 오염물질에 노출되 는 총 연수를 의미하는데, 미국의 경우 주거용지에서는 30 년, 상업·공업용지에서는 25 년을 기본값으로 제시하고 있 으며(US EPA), ${ }^{21)}$ 호주에서는 토지이용도를 구분하지 않고 30 년을 기본값으로 제시하고 있다(NEPC). ${ }^{23)}$ 우리나라의 경 우 대표값이 제시되기 전까지 주거지역 30년 그리고 상업공업지역의 경우 25 년을 적용할 것을 권고하고 있으나,9" 폐 금속광산 주민건강영향조사의 자료를 통해 주민들의 평균 거주기간인 성인남성 48.4년, 성인여성 41.9년, 그리고 어 린이 8.2 년을 적용하는 것이 보수적인 위해성평가 결과를 얻는데 타당할 것으로 보았다. 평균시간(average time, AT) 은 사람의 평생 동안의 노출을 고려하는 발암위해도 평가 에서 중요한 인자로, Table 1의 노출량 산정식들에서 보는 바와 같이 평균시간이 짧으면 노출량이 증가하여 잠재적 발암위해도가 커지고, 평균시간이 길어지면 잠재적 발암위 해도는 작아진다. 미국 환경청(US EPA), ${ }^{21)}$ 호주(NEPC), ${ }^{23)}$ 영국(EA) $)^{24)}$ 등에서는 위해성평가 시 실제 평균수명보다 적 은 70 년을 권장하고 있으나, 본 연구에서는 의료기술의 발 전에 따른 평균 수명 증가 현상을 반영하기 위하여 2013년 기준 기대수명자료 ${ }^{17)}$ 인 성인남성 78.51년, 성인여성 85.06년, 그리고 성인남성과 성인여성의 기대수명의 평균인 81.94년 을 어린이의 평균시간으로 적용하여 각각 일수로 환산하였 다. Table 1에 나타낸 바와 같이 표토피부접촉에 의한 노출 량 산정 시 토양 피부접촉체표면적(SAe)과 지표수피부접촉 에 의한 노출량 산정 시 물 피부접촉체표면적(SAw)을 이 용하고 있다. 이들 인자들을 계산하기 위해 먼저 체표면적 을 산정하였다. 본 연구에서는 우리나라 성인남성, 성인여 성, 어린이의 체표면적을 산출하기 위하여 폐금속 광산 주 민건강영향조사 보고서의 폐광산주민의 평균 체중(BW)과 신장(height, HW)을 Lee ${ }^{19)}$ 에 의해 제시된 체표면적 산출공 식(식 (1))에 대입하여 계산하였다. ${ }^{12 \sim 16)}$ 그 결과 체표면적 은 성인남성 $16,848 \mathrm{~cm}^{2}$, 성인여성 $15,612 \mathrm{~cm}^{2}$, 그리고 어 린이 $11,912 \mathrm{~cm}^{2}$ 로 산정되었다.

체표면적 $=73.31 \times \mathrm{BW}^{0.425} \times \mathrm{HT}^{0.725}$

$\mathrm{US} \mathrm{EPA}^{21)}$ 은 성인과 어린이의 체중과 신장을 이용하여 산출된 체표면적에서 의복착용을 제외한 체표면적의 $25 \%$ 를 토양 피부접촉체표면적(SAe)으로 제시하고 있다. ${ }^{2)}$ 본 연 구에서도 이와 같은 폐광산 지역 주민의 신장과 체중을 적 용하여 산출된 체표면적의 $25 \%$ 를 토양 피부접촉체표면적 (SAe)으로 고려하여, 성인남성 $4,212 \mathrm{~cm}^{2}$, 성인여성 3,903 $\mathrm{cm}^{2}$, 그리고 어린이 $2,978 \mathrm{~cm}^{2}$ 의 값을 도출하였다. 지표수 피부접촉에 의한 노출량 산정 시 이용되는 물 피부접촉체 표면적(SAw)은 국내 자료의 부족하여 US $\mathrm{EPA}^{21)}$ 에서 제시 한 성인남성 $23,000 \mathrm{~cm}^{2}$ 를 기준으로 하였으며, 성인여성과 어린이의 경우 토양 피부접촉체표면적(SAe)에서의 성인남 성에 대한 성인여성과 어린이 체표면적의 비를 고려하여 계산하였다. 그 외 토양-피부간 흡착계수(AF)와 물-피부간 
흡착두께(Thw)의 경우 국내 자료의 부족으로 US EPA 자 료 $^{22}$ 로부터 획득하였다. 또한 본 연구에서는 토양, 지하수, 농작물 섭취에 의한 노출경로를 고려하여, 이들에 의한 오 염물질 인체노출량 산정에 있어 Table 1과 같이 일일토양섭 취량 $(\mathrm{CRs})$, 일일지하수섭취량 $(\mathrm{CRw})$, 일일농작물섭취량 $(\mathrm{CRp})$ 이 필요하다. 일일토양섭취량 $(\mathrm{CRs})$ 은 오염된 토양의 섭취에 의한 경로 고려 시 중요한 인자로서 본 연구에서는 국내 제안된 자료가 없는 성인남성과 성인여성의 토양 섭취량은 $\mathrm{US} \mathrm{EPA}^{21)}$ 제시값과 동일하게 $50 \mathrm{mg} / \mathrm{day}$ 를 이용하였으나, 어린이의 경우 $\mathrm{ME}^{20)}$ 의 한국 노출계수 핸드북에 분변 내 알 루미늄 분석을 통해 추정된 값인 $118 \mathrm{mg} / \mathrm{day}$ 을 이용하였 다. 일일지하수섭취량 $(\mathrm{CRw})$ 은 미국과 네덜란드의 경우 위 해성 평가 시 $2 \mathrm{~L} / \mathrm{day}$, 어린이 $1 \mathrm{~L} / \mathrm{day}$ 로 적용할 것을 권장 하고 있으나, 여기에서는 $\mathrm{ME}^{20}$ 한국 노출계수 핸드북의 자 료를 이용하여 성인남성 $1.66 \mathrm{~L} / \mathrm{day}$, 성인여성 $1.35 \mathrm{~L} / \mathrm{day}$, 그리고 어린이의 경우에는 자료 부족으로 국내 오염토양 위해성평가지침에서 제시한 $1 \mathrm{~L} / \mathrm{day}$ 를 그대로 사용하였다. 농작물섭취는 폐광산지역의 인체위해성평가 시 중요한 노 출경로로서 이에 의한 노출량을 산정하기 위해서는 일일농 작물섭취량 $(\mathrm{CRp})$ 이 검토되어야 한다. 본 연구에서는 두 폐 금속 광산 지역 인근 농경지에 공통적으로 넓게 분포된 논 에서 생산되는 쌀만 고려하였다. 쌀의 섭취량( $\mathrm{CRp})$ 은 $\mathrm{ME}^{20)}$ 한국 노출계수 핸드북의 자료에서 제시된 곡류의 섭취량을 참고하여 성인남성 $0.440 \mathrm{~kg} / \mathrm{day}$, 성인여성 $0.386 \mathrm{~kg} / \mathrm{day}$, 어 린이 $0.336 \mathrm{~kg} / \mathrm{day}$ 값을 이용하였다. 그리고 토양-농작물 생 축적 계수(bio-concentration factor, $\mathrm{BCF}$ )는 국내외 자료 ${ }^{27,28)}$ 를 이용하여 획득하였으며, Table1의 6번째 노출경로인 농 작물섭취에 의한 노출량은 Table 3에 제시된 각 중금속 오 염물질별 $\mathrm{BCF}$ 와 Table 6의 표토노출농도 $(\mathrm{Cs})$ 를 이용하여 계 산하였다. 지금까지 언급한 수용체 특성과 관련된 노출인자 외 오염물질 및 환경 매질 특성과 연관된 노출인자들은 각 각 Tables 3과 4에 정리하였다. 대부분의 노출인자들에 대한 국내 자료가 없어서 주로 국외 자료를 적용하였다. 특히 상 술하였듯이 Fig. 1과 Table1에 있는 노출경로들 중 마지막 7 번째 경로는 본 연구에서 고려되지 않았기 때문에 이와 관 련된 노출인자와 노출량은 본 논문에서 제시하지 않았다.

\subsection{3. 독성자료}

본 단계에서는 선정된 5 종의 중금속 오염물질에 대한 독 성자료를 획득한다. 먼저 각 오염물질들의 발암성 여부는 미 국 환경보호청(EPA)의 통합위해정보시스템(integrated risk information system, IRIS)과 국제암연구소(international agency for research on cancer, IARC)의 자료를 바탕으로 하여, 본 연구에서는 $\mathrm{As}$ (섭취, 피부접촉 및 호흡 경로), $\mathrm{Cd}$ (호흡 경 로), $\mathrm{Pb}$ (섭취 및 호흡 경로) 등 3종의 오염물질을 발암물질 로 고려하였다. 그리고 각 오염물질별 독성자료를 통합위 해정보시스템(integrated risk information system, IRIS) 자료 를 바탕으로 하여 발암성 오염물질과 비발암성 오염물질별 로 Table 5 에 정리하였다.
Table 5. Toxicity values of each heavy metal contaminant

\begin{tabular}{|c|c|c|c|c|c|c|}
\hline & & As & $\mathrm{Cd}$ & $\mathrm{Cu}$ & $\mathrm{Pb}$ & $\mathrm{Zn}$ \\
\hline \multirow{3}{*}{$\begin{array}{l}\text { Carcino- } \\
\text { genic }\end{array}$} & $\begin{array}{l}\text { Oral slope factor } \\
\left(\mathrm{SF}_{\mathrm{o}}\right)(\mathrm{mg} / \mathrm{kg} \text {-day })^{-1}\end{array}$ & 1.5E0 & ND & ND & $8.5 \mathrm{E}-3$ & ND \\
\hline & $\begin{array}{l}\text { Dermal slope factor } \\
\left(\mathrm{SF}_{\text {abs }}\right)(\mathrm{mg} / \mathrm{kg} \text {-day })^{-1}\end{array}$ & $6.1 \mathrm{E}+1$ & ND & ND & ND & ND \\
\hline & $\begin{array}{l}\text { Inhalation unit risk } \\
\text { (URFinh) }\left(\mu \mathrm{g} / \mathrm{m}^{3}\right)^{-1}\end{array}$ & 4.3E-3 & $1.8 \mathrm{E}-3$ & ND & 1.2E-5 & ND \\
\hline \multirow{3}{*}{$\begin{array}{l}\text { Non- } \\
\text { carcino- } \\
\text { genic }\end{array}$} & $\begin{array}{l}\text { Oral reference dose } \\
\left(\mathrm{RfD} \mathrm{D}_{0}\right)(\mathrm{mg} / \mathrm{kg} \text {-day) }\end{array}$ & $3.0 \mathrm{E}-4$ & $5.0 \mathrm{E}-4$ & $1.4 \mathrm{E}-1$ & $5.0 \mathrm{E}-4$ & $3.0 \mathrm{E}-1$ \\
\hline & $\begin{array}{l}\text { Dermal reference dose } \\
\left(\mathrm{RfD}_{\mathrm{abs}}\right)(\mathrm{mg} / \mathrm{kg} \text {-day) }\end{array}$ & $2.9 \mathrm{E}-4$ & 1.3E-5 & ND & ND & ND \\
\hline & $\begin{array}{l}\text { Inhalation reference } \\
\text { dose }(\mathrm{RfC})\left(\mathrm{mg} / \mathrm{m}^{3}\right)\end{array}$ & ND & 7.0E-4 & 1.0E-3 & ND & ND \\
\hline
\end{tabular}

$\mathrm{ND}=$ not determined

\subsection{4. 위해도 결정}

본 단계에서는 Table 1에 주어진 각 노출경로별 노출량 산정식과 Table 2 4에 제시된 노출인자들을 이용하여 계산 된 노출량(일일 평균 노출량, $\mathrm{ADD}$ )과 독성자료(Table 5)를 이용하여 발암 및 비발암위해도를 계산한 후 최종적으로 위해여부를 판단하였다. 먼저 발암위해성을 나타내는 초과 발암위해도(excess cancer risk, ECR)는 노출량과 발암독성 치 자료를 이용하여 식 (2)와 같이 계산하여 노출경로별 값 을 구하였다. 그리고 식 (3)을 이용하여 평가대상 지역의 발 암위해성을 결정할 수 있는 총 초과발암위해도(total excess cancer risk, TCR)를 계산하였다. 최종적으로 TCR값과 일 반적인 허용 가능한 발암위해도인 $1 \times 10^{-6}$ 과 비교하여 발암 위해성 여부를 판단하였다.

초과발암위해도 $(\mathrm{ECR})=\mathrm{SF}($ or $\mathrm{URF}) \times \mathrm{ADD}$

총 초과발암위해도 $(\mathrm{TCR})=\Sigma \mathrm{ECR}$

또한 비발암위해도를 산정하기 위하여 일일 평균 노출량 (ADD)과 비발암독성치, 식 (4)를 이용하였다. 이로부터 노출 경로별 위험비율(hazard quotient, HQ)을 구하고, 모든 위험 비율(HQ)을 식 (5)와 같이 합산하여 위험지수(hazard index, $\mathrm{HI})$ 를 산출하였다. 최종적으로 위험지수(HI)가 1 보다 큰 경 우에는 비발암위해성이 있는 것으로 판단하였다.

위험비율 $(\mathrm{HQ})=\mathrm{ADD} / \mathrm{RfD}($ or $\mathrm{RfC})$

위험지수 $(\mathrm{HI})=\Sigma \mathrm{HQ}$

\section{3. 결과 및 고찰}

\section{1. 노출농도}

인체위해성평가를 위한 토양, 지표수, 지하수의 중금속(As, $\mathrm{Cd}, \mathrm{Cu}, \mathrm{Pb}, \mathrm{Zn}$ )에 대한 농도 분석결과를 Table 6에 제시하 였다. 먼저, 토양시료는 봉광산의 경우, As $0 \sim 29.9 \mathrm{mg} / \mathrm{kg}$, 
Table 6. Exposure concentration of heavy metal contaminants contained in environmental media

\begin{tabular}{|c|c|c|c|c|c|c|c|}
\hline Media & Mine & Statistics & As & $\mathrm{Cd}$ & $\mathrm{Cu}$ & $\mathrm{Pb}$ & $\mathrm{Zn}$ \\
\hline \multirow{10}{*}{$\begin{array}{c}\text { Surface } \\
\text { soil } \\
(\mathrm{mg} / \mathrm{kg})\end{array}$} & \multirow{5}{*}{$\begin{array}{c}\text { Bong } \\
\text { mine } \\
(\mathrm{N}=184)\end{array}$} & Minimum & ND & ND & ND & ND & ND \\
\hline & & Maximum & 29.9 & 10.4 & 73.4 & 159.5 & 552.4 \\
\hline & & Median & 3.3 & 4.2 & 22.0 & 31.5 & 87.4 \\
\hline & & Average & 3.8 & 4.4 & 25.7 & 36.0 & 116.6 \\
\hline & & $\begin{array}{l}\text { Exposure con- } \\
\text { centration (Cs) }\end{array}$ & 4.3 & 4.5 & 27.7 & 38.7 & 126.8 \\
\hline & \multirow{5}{*}{$\begin{array}{c}\text { Daejung } \\
\text { mine } \\
(\mathrm{N}=252)\end{array}$} & Minimum & 0.9 & 1.4 & 10.5 & 10.5 & 31.6 \\
\hline & & Maximum & 24.4 & 6.5 & 103.5 & 123.2 & 166.4 \\
\hline & & Median & 4.3 & 3.2 & 23.9 & 30.0 & 51.1 \\
\hline & & Average & 5.3 & 3.3 & 31.0 & 31.2 & 55.7 \\
\hline & & $\begin{array}{l}\text { Exposure con- } \\
\text { centration (Cs) }\end{array}$ & 5.7 & 3.4 & 33.2 & 32.8 & 58.2 \\
\hline \multirow{10}{*}{$\begin{array}{c}\text { Ground- } \\
\text { water } \\
\text { (mg/L) }\end{array}$} & \multirow{5}{*}{$\begin{array}{l}\text { Bong } \\
\text { mine } \\
(\mathrm{N}=6)\end{array}$} & Minimum & ND & ND & ND & ND & 0.020 \\
\hline & & Maximum & 0.060 & ND & 0.020 & ND & 0.120 \\
\hline & & Median & ND & ND & 0.010 & ND & 0.075 \\
\hline & & Average & 0.010 & ND & 0.010 & ND & 0.077 \\
\hline & & $\begin{array}{l}\text { Exposure con- } \\
\text { centration (Cw) }\end{array}$ & 0.010 & - & 0.010 & - & 0.077 \\
\hline & \multirow{5}{*}{$\begin{array}{c}\text { Daejung } \\
\text { mine } \\
(\mathrm{N}=6)\end{array}$} & Minimum & ND & ND & ND & ND & 0.015 \\
\hline & & Maximum & ND & 0.004 & 0.024 & 0.088 & 0.075 \\
\hline & & Median & ND & ND & ND & ND & 0.020 \\
\hline & & Average & ND & 0.001 & 0.008 & 0.029 & 0.036 \\
\hline & & $\begin{array}{l}\text { Exposure con- } \\
\text { centration (Cw) }\end{array}$ & - & 0.001 & 0.008 & 0.029 & 0.036 \\
\hline \multirow{10}{*}{$\begin{array}{c}\text { Surface } \\
\text { water } \\
\text { (mg/L) }\end{array}$} & \multirow{5}{*}{$\begin{array}{l}\text { Bong } \\
\text { mine } \\
(\mathrm{N}=5)\end{array}$} & Minimum & ND & ND & ND & ND & ND \\
\hline & & Maximum & ND & ND & ND & ND & 0.020 \\
\hline & & Median & ND & ND & ND & ND & ND \\
\hline & & Average & ND & ND & ND & ND & 0.006 \\
\hline & & $\begin{array}{l}\text { Exposure con- } \\
\text { centration (Csw) }\end{array}$ & - & - & - & - & 0.006 \\
\hline & \multirow{5}{*}{$\begin{array}{c}\text { Daejung } \\
\text { mine } \\
(\mathrm{N}=5)\end{array}$} & Minimum & ND & ND & ND & ND & 0.121 \\
\hline & & Maximum & ND & ND & ND & ND & 0.165 \\
\hline & & Median & ND & ND & ND & ND & 0.139 \\
\hline & & Average & ND & ND & ND & ND & 0.138 \\
\hline & & $\begin{array}{l}\text { Exposure con- } \\
\text { centration (Csw) }\end{array}$ & - & - & - & - & 0.138 \\
\hline
\end{tabular}

$\mathrm{ND}=$ not detected

$\mathrm{Cd} 0 \sim 10.4 \mathrm{mg} / \mathrm{kg}, \mathrm{Cu} 0 \sim 73.4 \mathrm{mg} / \mathrm{kg}, \mathrm{Pb} 0 \sim 159.5 \mathrm{mg} / \mathrm{kg}$, 그리 고 $\mathrm{Zn} 0 \sim 552.4 \mathrm{mg} / \mathrm{kg}$ 의 농도 범위를 보였으며, 대정광산은 As $0.9 \sim 24.4 \mathrm{mg} / \mathrm{kg}, \mathrm{Cd} 1.4 \sim 6.5 \mathrm{mg} / \mathrm{kg}, \mathrm{Cu} 10.5 \sim 103.5 \mathrm{mg} / \mathrm{kg}$, $\mathrm{Pb} 10.5 \sim 123.2 \mathrm{mg} / \mathrm{kg}$, 그리고 $\mathrm{Zn} 31.6 \sim 166.4 \mathrm{mg} / \mathrm{kg}$ 의 범위를 나타내었다. 지하수의 경우를 살펴보면, 봉광산에서는 $\mathrm{Cd}$ 와 $\mathrm{Pb}$ 는 검출되지 않았고 $\mathrm{Cu}$ 와 $\mathrm{As}$ 는 $0.01 \mathrm{mg} / \mathrm{L}$ 수준, $\mathrm{Zn}$ 은 0.02 $0.12 \mathrm{mg} / \mathrm{L}$ 정도의 농도분포를 나타냈다. 대정광산에서는 $\mathrm{As}$ 가 검출되지 않았으며, $\mathrm{Cd} 0 \sim 0.004 \mathrm{mg} / \mathrm{L}, \mathrm{Cu} 0 \sim 0.024 \mathrm{mg} / \mathrm{L}$, $\mathrm{Pb} 0 \sim 0.088 \mathrm{mg} / \mathrm{L}$, 그리고 $\mathrm{Zn} 0.015 \sim 0.075 \mathrm{mg} / \mathrm{L}$ 범위의 농도 를 보였다. 하천수의 경우 두 광산 모두에서 $\mathrm{As}, \mathrm{Cd}, \mathrm{Cu}, \mathrm{Pb}$ 은 검출되지 않았으며, $\mathrm{Zn}$ 은 봉광산에서 $0 \sim 0.02 \mathrm{mg} / \mathrm{L}$, 대 정광산에서 $0.121 \sim 0.165 \mathrm{mg} / \mathrm{L}$ 의 농도분포를 나타냈다.
Table 1에 주어진 각 노출경로별 노출량 산정식을 보면 각 매질별 노출농도가 필요하다. 본 연구에서는 두 가지 방 법으로 각 매질별 노출농도를 결정하였다. 먼저 표토의 노 출농도 $(\mathrm{Cs})$ 를 산정할 때는 본 위해성평가를 위해 분석된 표토시료(봉광산 184 개, 대정광산 252개)에 대하여 국내 토 양오염물질 위해성평가지침 ${ }^{29)}$ 에서 제시하고 있는 통계처리 를 이용하여 상위 $95 \%$ 신뢰값을 표토노출농도 $(\mathrm{Cs})$ 로 결정 하였다(식 (6)). 하지만 지하수와 지표수의 경우 시료개수가 충분하지 않아서 분석된 결과의 평균농도를 지하수노출농 도 $(\mathrm{Cw})$ 와 지표수노출농도 $(\mathrm{Csw})$ 로 사용하였다.

$\mathrm{Cs}=$ 상위 $95 \%$ 신뢰값 $=x+t_{95 \%, d f} \frac{\sigma}{\sqrt{N}}$

여기서, $\mathrm{x}$ 와 $\sigma$ 는 각각 분석농도의 평균값과 표준편차이고,

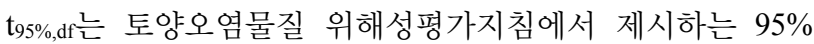
t-통계값, $\mathrm{N}$ 은 토양오염물질 위해성평가지침에서 요구하고 있는 통계학적으로 유의한 시료채취개수이다.

\section{2. 노출량}

Table 1에 제시된 노출량 산정식과 Table 2 4의 노출인자, Table 6에 주어진 각 매체별 노출농도를 이용하여 각 광산 별 노출량(일일 평균 노출량, $\mathrm{ADD}$ )을 계산하여 그 결과를 Table 7과 8에 정리하였다. 몇 가지 노출경로의 경우 노출량

Table 7. The results of average daily dose (ADD) for the Bong mine

\begin{tabular}{|c|c|c|c|c|c|c|c|}
\hline & & $\begin{array}{l}\text { Surface } \\
\text { soil oral } \\
\text { (mg/kg- } \\
\text { day) } \\
\end{array}$ & $\begin{array}{c}\text { Surface } \\
\text { soil der- } \\
\text { mal (mg/ } \\
\text { kg-day) }\end{array}$ & $\begin{array}{c}\text { Surface } \\
\text { soil } \\
\text { inhalation } \\
\left(\mathrm{mg} / \mathrm{m}^{3}\right) \\
\end{array}$ & $\begin{array}{l}\text { Ground- } \\
\text { water } \\
\text { oral (mg/ } \\
\text { kg-day) }\end{array}$ & $\begin{array}{c}\text { Surface } \\
\text { water der- } \\
\text { mal (mg/ } \\
\text { kg-day) }\end{array}$ & $\begin{array}{c}\text { Crop } \\
\text { oral } \\
\text { (mg/kg- } \\
\text { day) } \\
\end{array}$ \\
\hline \multirow{3}{*}{ As } & $\begin{array}{l}\text { Adult } \\
\text { male }\end{array}$ & 2.02E-06 & $3.75 \mathrm{E}-07$ & 6.67E-08 & 1.64E-04 & ND & $5.15 \mathrm{E}-04$ \\
\hline & $\begin{array}{l}\text { Adult } \\
\text { female }\end{array}$ & 1.67E-06 & 2.89E-07 & 5.33E-08 & 1.11E-04 & ND & $3.74 \mathrm{E}-04$ \\
\hline & Child & $1.28 \mathrm{E}-06$ & 2.05E-07 & $1.08 \mathrm{E}-08$ & 2.67E-05 & ND & 1.06E-04 \\
\hline \multirow{3}{*}{$\mathrm{Cd}$} & $\begin{array}{l}\text { Adult } \\
\text { male }\end{array}$ & 5.55E-08 & 1.83E-06 & $6.98 \mathrm{E}-08$ & ND & ND & 3.96E-05 \\
\hline & $\begin{array}{l}\text { Adult } \\
\text { female }\end{array}$ & 4.60E-08 & $1.41 \mathrm{E}-06$ & $5.58 \mathrm{E}-08$ & ND & ND & $2.88 \mathrm{E}-05$ \\
\hline & Child & $3.54 \mathrm{E}-08$ & $1.00 \mathrm{E}-06$ & $1.13 \mathrm{E}-08$ & ND & ND & 8.17E-06 \\
\hline \multirow{3}{*}{$\mathrm{Cu}$} & $\begin{array}{l}\text { Adult } \\
\text { male }\end{array}$ & 7.79E-06 & 8.06E-06 & 4.30E-07 & 1.64E-04 & ND & ND \\
\hline & $\begin{array}{l}\text { Adult } \\
\text { female }\end{array}$ & $6.46 \mathrm{E}-06$ & 6.20E-06 & $3.43 \mathrm{E}-07$ & $1.11 \mathrm{E}-04$ & ND & ND \\
\hline & Child & 4.97E-06 & 4.40E-06 & $6.98 \mathrm{E}-08$ & 2.67E-05 & $\mathrm{ND}$ & ND \\
\hline \multirow{3}{*}{$\mathrm{Pb}$} & $\begin{array}{l}\text { Adult } \\
\text { male }\end{array}$ & ND & 6.76E-07 & $6.01 \mathrm{E}-07$ & ND & ND & ND \\
\hline & $\begin{array}{c}\text { Adult } \\
\text { female }\end{array}$ & ND & 5.19E-07 & $4.80 \mathrm{E}-07$ & ND & ND & ND \\
\hline & Child & ND & 3.69E-07 & $9.75 \mathrm{E}-08$ & ND & ND & ND \\
\hline \multirow{3}{*}{ Zn } & $\begin{array}{l}\text { Adult } \\
\text { male }\end{array}$ & ND & 7.38E-06 & $1.97 \mathrm{E}-06$ & 1.26E-03 & 6.37E-08 & ND \\
\hline & $\begin{array}{l}\text { Adult } \\
\text { female }\end{array}$ & ND & 5.67E-06 & $1.57 \mathrm{E}-06$ & 8.51E-04 & 4.90E-08 & ND \\
\hline & Child & ND & 4.03E-06 & $3.19 \mathrm{E}-07$ & 2.05E-04 & $+1.22 \mathrm{E}-08$ & ND \\
\hline
\end{tabular}

$\mathrm{ND}=$ not determined 
Table 8. The results of average daily dose (ADD) for the Daejung mine

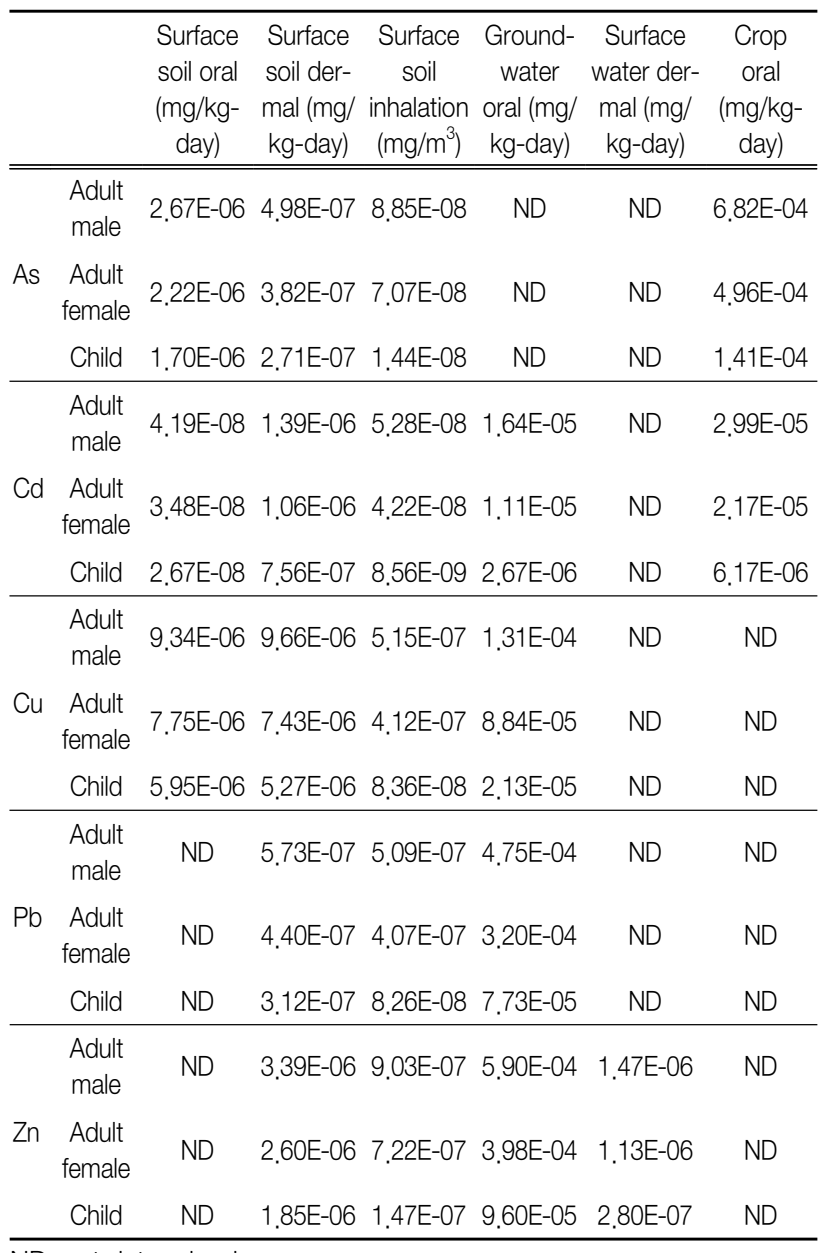

$\mathrm{ND}=$ not determined

이 산정되지 않았는데 노출인자, 노출농도 등이 부재한 까 닭이다. 먼저 노출인자가 없어서 노출량이 산정되지 않은 경우를 살펴보면, $\mathrm{Cu}$ 의 농작물섭취경로에 따른 노출량은 Table 3과 같이 생축적계수 $(\mathrm{BCF})$ 가 없기 때문이고, $\mathrm{Pb}$ 와 $\mathrm{Zn}$ 는 역시 Table 3에서 보는 바와 같이 체내흡수계수 $\left(\mathrm{ABS}_{\mathrm{GI}}\right)$ 에 대한 자료의 부재로 인하여 표토섭취와 농작물섭취 경 로에 의한 노출량을 결정할 수 없었다. 그리고 매질 내 중 금속 오염물질이 검출되지 않아 노출농도를 결정할 수 없 기 때문에 노출량이 계산되지 않은 경우들로는 먼저 지하 수섭취경로에서 봉광산 $\mathrm{Cd}$ 와 $\mathrm{Pb}$, 대정광산 $\mathrm{As}$ 이었다. 지표 수피부접촉경로에서는 두 광산 모두 $\mathrm{Zn}$ 을 제외한 나머지 4 종의 오염물질 $(\mathrm{As}, \mathrm{Cd}, \mathrm{Cu}, \mathrm{Pb})$ 은 노출농도가 없어서 노출 량을 결정할 수 없었다.

노출경로별 노출량을 비교하면 $\mathrm{As}$ 의 경우에는 농작물섭 취 $\approx$ 지하수섭취 $>$ 표토섭취 $>$ 표토피부접촉 $>$ 표토흡입, $\mathrm{Cd}$ 인 경우 농작물섭취 $\approx$ 지하수섭취> 표토피부접촉>표토 섭취 $\approx$ 표토흡입, $\mathrm{Cu}$ 인 경우 지하수섭취>표토섭취 $\approx$ 표토 피부접촉> 표토흡입, $\mathrm{Pb}$ 는 지하수섭취>표토피부접촉 $\approx$ 표토흡입, 마지막으로 $\mathrm{Zn}$ 은 지하수섭취>표토피부접촉 $~$ 표토흡입 > 지표수피부접촉 등의 순위로 나타나서, 농작물섭
취와 지하수섭취가 주요한 노출경로로 조사되었다.

동일한 노출경로에서 중금속 오염물질 종류별 노출량을 비교하면, 표토섭취인 경우 $\mathrm{Cu} \approx \mathrm{As}>\mathrm{Cd}$, 표토피부접촉 $\mathrm{Cu} \approx \mathrm{Zn} \approx \mathrm{Cd}>\mathrm{Pb} \approx \mathrm{As}$, 표토호흡 $\mathrm{Zn}>\mathrm{Pb} \approx \mathrm{Cu}>\mathrm{Cd} \approx$ $\mathrm{As}$, 지하수섭취 $\mathrm{Zn} \approx \mathrm{Pb}>\mathrm{Cu}>\mathrm{Cd}$, 지표수피부접촉 $\mathrm{Zn}$ 등 의 순서로 나타났다. Table6에 제시된 각 중금속별 노출농 도는 표토의 경우 $\mathrm{Zn}>\mathrm{Pb} \approx \mathrm{Cu}>\mathrm{As} \approx \mathrm{Cd}$, 지하수는 $\mathrm{Zn}>$ $\mathrm{Pb}>\mathrm{Cu} \approx \mathrm{As} \approx \mathrm{Cd}$, 지표수는 $\mathrm{Zn}$ 등의 순으로 높게 나타난 다. 앞에서 살펴본 중금속별 노출량은 노출농도의 분포양 상과는 다소 상이한 결과를 보인다. 이는 중금속 오염물질 별 노출량은 각 중금속별 노출농도에 의해서 영향을 받지만, 그 보다는 Table 3에 제시된 각 오염물질별 특성을 반영한 노출인자, 특히 체내흡수계수 $\left(\mathrm{ABS}_{\mathrm{GI}}\right)$, 피수흡수계수 $\left(\mathrm{ABS}_{\mathrm{D}}\right)$ 호흡흡수계수 $\left(\mathrm{ABS}_{\mathrm{inh}}\right)$ 에 더 영향을 받는 것으로 판단된다. 또한 수용체별 노출량은 비교해 보면, 예상되는 바와 같 이 동일한 노출경로와 동일한 중금속 종에서 성인남성> 성 인여성> 어린이 순으로 나타났다. 이는 노출경로와 오염물 질의 노출농도가 동일하지만 Table 2에 제시된 수용체별 특 성이 반영된 결과이다. 마지막으로 두 광산별 노출량을 비 교하면, 각 노출경로별 동일한 중금속 종의 노출농도에 따 라 상이하게 나타나는 것으로 판단된다. 즉 노출인자 값들 은 동일하게 적용되기 때문에 각 매질별 노출농도가 두 광 산별 노출량을 좌우한다. 예를 들어, $\mathrm{Pb}$ 의 경우 Table6에 제 시된 표토노출농도 $(\mathrm{Cs})$ 가 봉광산과 대정광산에서 각각 38.7 과 $32.8 \mathrm{mg} / \mathrm{kg}$ 으로 유사하기 때문에 두 광산의 표토피부접 촉 및 표토호흡 노출량이 비슷하게 결정되었다. 이와는 다르 게 $\mathrm{Zn}$ 의 두 광산별 표토노출농도 $(\mathrm{Cs})$ 는 봉광산에서 126.8 $\mathrm{mg} / \mathrm{kg}$, 대정광산에서 $58.2 \mathrm{mg} / \mathrm{kg}$ 으로 산정되어, 이러한 노 출농도가 반영된 표토피부접촉 및 표토호흡 경로의 노출량 은 대정광산보다는 봉광산에서 더 크게 나타났다.

\section{3. 발암 및 비발암 위해도}

각 중금속 오염물질별 독성자료(Table 5), 노출량(Table 7, 8), 그리고 식 (2) (5)를 이용하여 계산한 각 광산별 발암 및 비발암위해도를 Table 9 10, Fig. 2 5에 제시하였다. 지표 수피부접촉경로에 대한 발암 및 비발암위해도가 결정되지 않은 이유는 지표수에서 $\mathrm{Zn}$ 만이 검출되어 Table 6에서 보 는 바와 같이 $\mathrm{Zn}$ 에 대한 노출농도만 존재하고, 따라서 이 경로에 대한 노출량은 $\mathrm{Zn}$ 만이 계산되었다(Table 7,8 ). 하지 만, Table 5에 제시된 바와 같이 $\mathrm{Zn}$ 의 피부흡수발암계수 $\left(\mathrm{SF}_{\mathrm{abs}}\right)$ 와 피부흡수비발암참고치 $\left(\mathrm{RfD}_{\mathrm{abs}}\right)$ 가 없기 때문에 지 표수피부접촉경로에 대한 발암 및 비발암위해도는 결정할 수 없었다.

먼저 발암위해도를 살펴보면 두 광산 모두에서 총 초과 발암위해도(total excess cancer risk, TCR)는 모든 수용체에 대하여 허용 가능한 발암위해도인 $1 \times 10^{-6}$ 의 값보다 크게 조 사되어 발암위해성이 있는 것으로 판명되었다. 또한 앞서 언급한 지표수피부접촉경로를 제외한 모든 노출경로에서 허용 가능한 발암위해도보다 높은 초과발암위해도(excess 
Table 9. Carcinogenic and non-carcinogenic risks

\begin{tabular}{|c|c|c|c|c|c|c|c|c|c|}
\hline \multirow{8}{*}{ Carcinogenic } & & & \multicolumn{6}{|c|}{ Excess cancer risk (ECR) } & \multirow{2}{*}{$\begin{array}{c}\text { Total excess } \\
\text { cancer risk } \\
\text { (TCR) }\end{array}$} \\
\hline & & & $\begin{array}{l}\text { Surface soil } \\
\text { oral }\end{array}$ & $\begin{array}{l}\text { Surface soil } \\
\text { dermal }\end{array}$ & $\begin{array}{l}\text { Surface soil } \\
\text { inhalation }\end{array}$ & $\begin{array}{c}\text { Groundwater } \\
\text { oral }\end{array}$ & $\begin{array}{c}\text { Surface water } \\
\text { dermal }\end{array}$ & Crop oral & \\
\hline & \multirow{3}{*}{$\begin{array}{l}\text { Bong } \\
\text { mine }\end{array}$} & Adult male & $3.02 \mathrm{E}-06$ & $2.29 E-05$ & $4.20 \mathrm{E}-07$ & $2.46 \mathrm{E}-04$ & ND & $7.72 \mathrm{E}-04$ & $1.04 \mathrm{E}-03$ \\
\hline & & Adult female & $2.51 \mathrm{E}-06$ & 1.76E-05 & 3.35E-07 & 1.66E-04 & ND & $5.61 \mathrm{E}-04$ & 7.47E-04 \\
\hline & & Child & 1.93E-06 & 1.25E-05 & $6.81 \mathrm{E}-08$ & 4.00E-05 & ND & $1.59 \mathrm{E}-04$ & 2.14E-04 \\
\hline & \multirow{3}{*}{$\begin{array}{l}\text { Daejung } \\
\text { mine }\end{array}$} & Adult male & 4.01E-06 & 3.04E-05 & 4.81E-07 & 4.04E-06 & ND & 1.02E-03 & 1.06E-03 \\
\hline & & Adult female & 3.32E-06 & 2.33E-05 & 3.85E-07 & 2.72E-06 & ND & $7.44 \mathrm{E}-04$ & 7.74E-04 \\
\hline & & Child & 2.55E-06 & 1.66E-05 & 7.81E-08 & $6.57 \mathrm{E}-07$ & ND & $2.11 \mathrm{E}-04$ & 2.31E-04 \\
\hline \multirow{8}{*}{$\begin{array}{c}\text { Non- } \\
\text { carcinogenic }\end{array}$} & & & \multicolumn{6}{|c|}{ Hazard quotient (HQ) } & \multirow{2}{*}{$\begin{array}{l}\text { Hazard index } \\
(\mathrm{HI})\end{array}$} \\
\hline & & & $\begin{array}{l}\text { Surface soil } \\
\text { oral }\end{array}$ & $\begin{array}{l}\text { Surface soil } \\
\text { dermal }\end{array}$ & $\begin{array}{l}\text { Surface soil } \\
\text { inhalation }\end{array}$ & $\begin{array}{c}\text { Groundwater } \\
\text { oral }\end{array}$ & $\begin{array}{c}\text { Surface water } \\
\text { dermal }\end{array}$ & Crop oral & \\
\hline & \multirow{3}{*}{$\begin{array}{l}\text { Bong } \\
\text { mine }\end{array}$} & Adult male & $6.89 \mathrm{E}-03$ & $1.42 \mathrm{E}-01$ & 5.30E-04 & $5.51 \mathrm{E}-01$ & ND & $1.76 \mathrm{E}+00$ & $2.46 \mathrm{E}+00$ \\
\hline & & Adult female & $5.71 \mathrm{E}-03$ & 1.09E-01 & 4.23E-04 & $3.72 \mathrm{E}-01$ & ND & $1.28 \mathrm{E}+00$ & $1.76 \mathrm{E}+00$ \\
\hline & & Child & 4.39E-03 & 7.76E-02 & 8.60E-05 & 8.97E-02 & ND & $3.62 \mathrm{E}-01$ & $5.34 \mathrm{E}-01$ \\
\hline & \multirow{3}{*}{$\begin{array}{l}\text { Daejung } \\
\text { mine }\end{array}$} & Adult male & 9.06E-03 & $1.08 \mathrm{E}-01$ & 5.91E-04 & $9.86 \mathrm{E}-01$ & ND & $2.30 \mathrm{E}+00$ & $3.41 \mathrm{E}+00$ \\
\hline & & Adult female & 7.51E-03 & 8.32E-02 & 4.72E-04 & 6.65E-01 & ND & $1.67 \mathrm{E}+00$ & $2.43 \mathrm{E}+00$ \\
\hline & & Child & 5.77E-03 & 5.91E-02 & 9.59E-05 & 1.60E-01 & ND & $4.76 \mathrm{E}-01$ & 7.01E-01 \\
\hline
\end{tabular}

$\mathrm{ND}=$ not determined

Table 10. Relative contribution of each exposure pathway to the carcinogenic and non-carcinogenic risks

(unit: \%)

\begin{tabular}{|c|c|c|c|c|c|c|c|c|c|}
\hline \multirow{8}{*}{ Carcinogenic } & & & \multicolumn{6}{|c|}{ Excess cancer risk (ECR) } & \multirow{2}{*}{$\begin{array}{c}\text { Total excess } \\
\text { cancer risk } \\
\text { (TCR) }\end{array}$} \\
\hline & & & $\begin{array}{l}\text { Surface soil } \\
\text { oral }\end{array}$ & $\begin{array}{c}\text { Surface soil } \\
\text { dermal }\end{array}$ & $\begin{array}{l}\text { Surface soil } \\
\text { inhalation }\end{array}$ & $\begin{array}{c}\text { Groundwater } \\
\text { oral }\end{array}$ & $\begin{array}{c}\text { Surface water } \\
\text { dermal }\end{array}$ & Crop oral & \\
\hline & \multirow{3}{*}{$\begin{array}{l}\text { Bong } \\
\text { mine }\end{array}$} & Adult male & 0.29 & 2.19 & 0.04 & 23.53 & - & 73.94 & 100 \\
\hline & & Adult female & 0.34 & 2.36 & 0.04 & 22.18 & - & 75.08 & 100 \\
\hline & & Child & 0.90 & 5.84 & 0.03 & 18.70 & - & 74.52 & 100 \\
\hline & \multirow{3}{*}{$\begin{array}{l}\text { Daejung } \\
\text { mine }\end{array}$} & Adult male & 0.38 & 2.86 & 0.05 & 0.38 & - & 96.34 & 100 \\
\hline & & Adult female & 0.43 & 3.02 & 0.05 & 0.35 & - & 96.15 & 100 \\
\hline & & Child & 1.11 & 7.17 & 0.03 & 0.28 & - & 91.41 & 100 \\
\hline \multirow{8}{*}{$\begin{array}{c}\text { Non- } \\
\text { carcinogenic }\end{array}$} & & & \multicolumn{6}{|c|}{ Hazard quotient (HQ) } & \multirow{2}{*}{$\begin{array}{l}\text { Hazard index } \\
(\mathrm{HI})\end{array}$} \\
\hline & & & $\begin{array}{l}\text { Surface soil } \\
\text { oral }\end{array}$ & $\begin{array}{l}\text { Surface soil } \\
\text { dermal }\end{array}$ & $\begin{array}{l}\text { Surface soil } \\
\text { inhalation }\end{array}$ & $\begin{array}{c}\text { Groundwater } \\
\text { oral }\end{array}$ & $\begin{array}{c}\text { Surface water } \\
\text { dermal }\end{array}$ & $\begin{array}{l}\text { Crop } \\
\text { oral }\end{array}$ & \\
\hline & \multirow{3}{*}{$\begin{array}{l}\text { Bong } \\
\text { mine }\end{array}$} & Adult male & 0.28 & 5.79 & 0.02 & 22.45 & - & 71.46 & 100 \\
\hline & & Adult female & 0.32 & 6.20 & 0.02 & 21.10 & - & 72.35 & 100 \\
\hline & & Child & 0.82 & 14.54 & 0.02 & 16.80 & - & 67.83 & 100 \\
\hline & \multirow{3}{*}{$\begin{array}{l}\text { Daejung } \\
\text { mine }\end{array}$} & Adult male & 0.27 & 3.18 & 0.02 & 28.93 & - & 67.61 & 100 \\
\hline & & Adult female & 0.31 & 3.42 & 0.02 & 27.36 & - & 68.89 & 100 \\
\hline & & Child & 0.82 & 8.43 & 0.01 & 22.89 & - & 67.85 & 100 \\
\hline
\end{tabular}

cancer risk, ECR)를 보였다(Table 9). 각 광산별로 발암위해 도를 좀 더 세밀하게 검토해 보면, 봉광산의 경우 농작물섭 취경로의 $\mathrm{ECR}$ 이 가장 큰 것으로 나타났으며 $\mathrm{TCR}$ 에 대한 기여율은 수용체별로 약 73.9 75.1\%로 나타났다(Table 10). 그 다음으로 지하수섭취경로(기여율 18.7 23.5 \%, Table 10) 에 의한 ECR이 크게 나타났다(Fig. 2(a)). 따라서 이 두 경 로의 TCR에 대한 기여율은 약 93.2 97.5\%로 봉광산에서 대부분의 발암위해도는 농작물섭취와 지하수섭취에 의한 것으로 조사되었다. 또한 중금속 오염물질 중에서는 As가
가장 큰 ECR을 나타냈는데(Fig. 2(b)), 이는 Table 6에 제시 된 As의 노출농도와 Table 7과 8에 나타난 $\mathrm{As}$ 의 노출량이 다른 오염물질에 비해 높지 않지만, 다른 중금속 오염물질 과 비교하여 노출경로별 발암독성치가 모두 존재하기 때문 이다(Table 5). 즉 As의 경우에는 모든 노출경로에 대한 발 암위해도가 계산되기 때문에 상대적으로 다른 중금속 오염 물질보다 큰 $\mathrm{ECR}$ 값을 나타낸다. 대정광산의 경우에도 발암 위해도가 유사하게 나타났는데, 역시 농작물섭취경로의 ECR 이 가장 높게 나타났다(Fig.3(a)). 이 경로의 TCR에 대한 기 

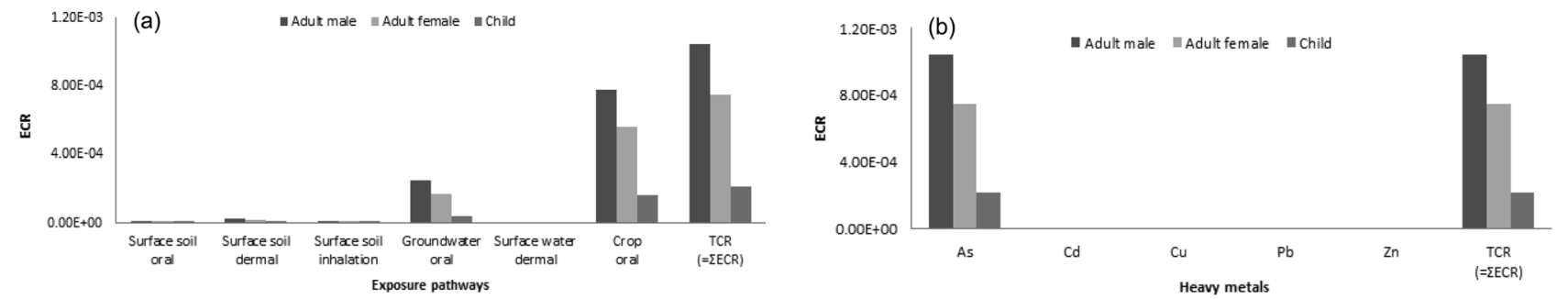

Fig. 2. Carcinogenic risk of each exposure pathway (a) and heavy metal contaminant (b) for the Bong mine.
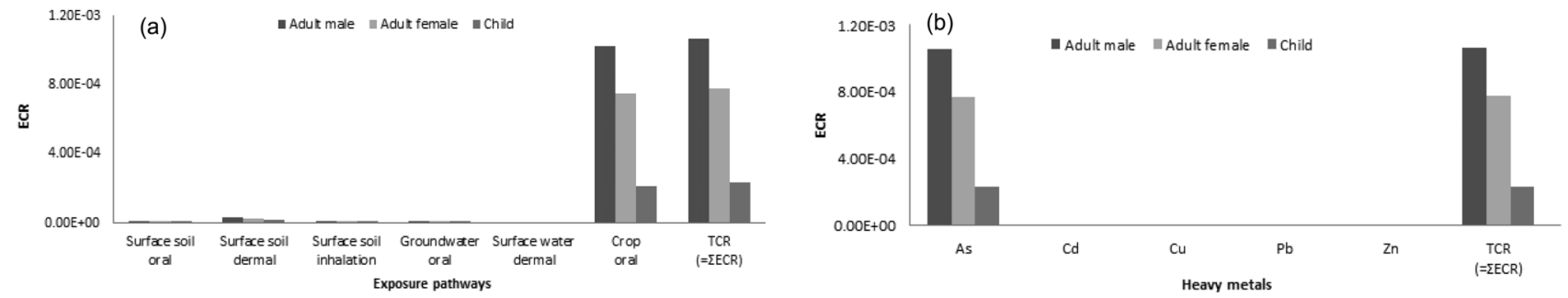

Fig. 3. Carcinogenic risk of each exposure pathway (a) and heavy metal contaminant (b) for the Daejung mine.
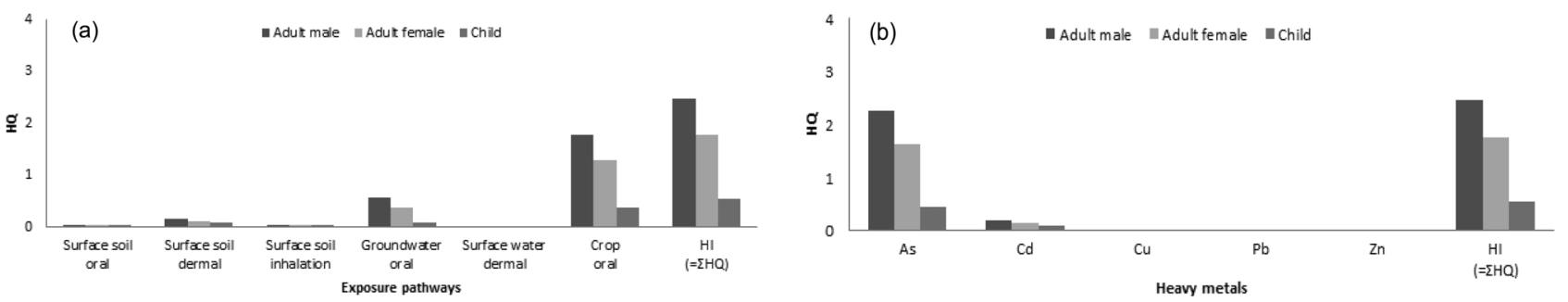

Fig. 4. Non-carcinogenic risk of each exposure pathway (a) and heavy metal contaminant (b) for the Bong mine.
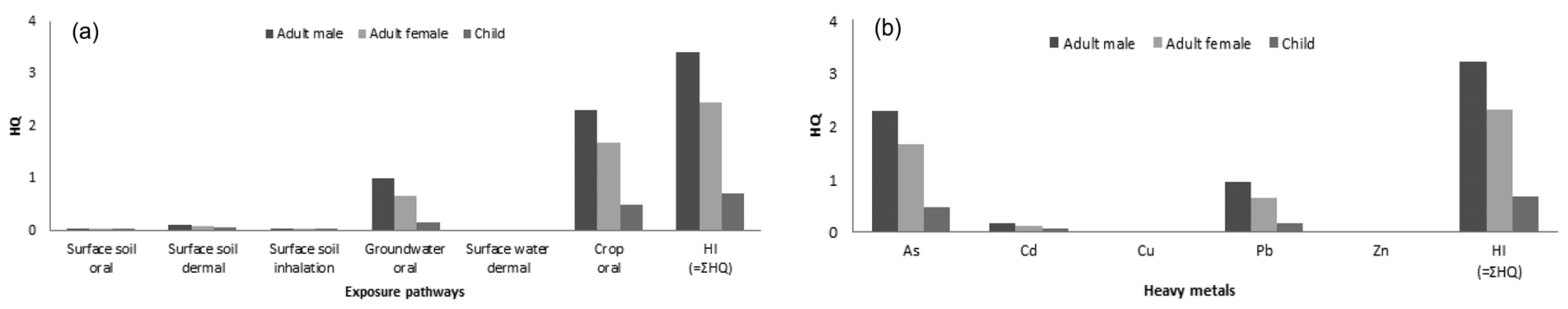

Fig. 5. Non-carcinogenic risk of each exposure pathway (a) and heavy metal contaminant (b) for the Daejung mine.

여율은 91.4 96.3\%(Table 10)로 조사되어져 대정광산의 경 우에는 대부분의 발암위해성이 농작물섭취에 의한 것으로 판단된다. 또한 대정광산에서도 $\mathrm{As}$ 가 발암위해도가 가장 큰 오염물질로 나타났다(Fig. 3(b)).

비발암위해도를 살펴보면, 두 광산 모두에서 성인에 대한 위험지수(hazard index, HI)가 1보다 큰 값을 보여 비발암 위해성이 있는 것으로 나타났고, 어린이의 경우에는 HI가 1 보다 작게 나타나 상대적으로 비발암위해성이 낮은 것으로 조사되었다(Table 9). 봉광산의 경우, 노출경로별 위험비율 (hazard quotient, HQ)을 비교해 보면 농작물섭취경로와 지 하수섭취경로에서 높게 나타났으며(Fig.4(a)), 이들 두 경로 의 $\mathrm{HI}$ 에 대한 기여율은 각각 $67.8 \sim 72.4 \%$ 와 $16.8 \sim 22.5 \%$ 인 것으로 조사되었다(Table 10). 따라서 봉광산에서는 비발암 위해성의 84.6 93.9\%가 농작물섭취 및 지하수섭취에 의해 서 초래되는 것으로 나타났다. 오염물질별 $\mathrm{HQ}$ 를 살펴보면,
발암위해도와 유사하게 As가 가장 큰 비발암위해성을 야기 하는 것으로 나타났으며(Fig.4(b)), As의 $\mathrm{HI}$ 에 대한 기여율 은 수용체별로 83.9 92.4\%로 계산되었다. 발암위해도와 비 교했을 때 상대적으로 $\mathrm{Cd}$ 의 $\mathrm{HI}$ 에 대한 기여율(7.4 16.0\%) 이 좀 터 크게 나타났는데, 이는 Table 5에서 보는 바와 같 이 $\mathrm{Cd}$ 에 대한 비발암 독성자료가 $\mathrm{As}$ 를 제외한 다른 오염 물질보다 더 많기 때문인 것으로 사료된다. 즉 $\mathrm{Cd}$ 의 경우 모 든 노출경로에서 $\mathrm{HQ}$ 를 산정할 수 있기 때문에 그에 따라 서 비발암위해성에 대한 기여율이 증가한 것으로 판단된다. 대정광산의 비발암위해도를 살펴보면, 농작물섭취경로(기 여율 67.6 68.9\%, Table 10)와 지하수섭취경로(기여율 22.9 $28.9 \%$, Table 10)의 HQ가 가장 높게 나타났다(Fig. 5(a)). 봉광산과 비교하였을 때 상대적으로 지하수섭취경로의 기여 율이 좀 더 큰 것으로 조사되었다. 대정광산의 오염물질별 $\mathrm{HQ}$ 를 검토해 보면, $\mathrm{As}$ 와 $\mathrm{Pb}$ 의 $\mathrm{HQ}$ 가 가장 높게 나타났으며 
(Fig. 5(b)), 이들 오염물질의 HI에 대한 기여율은 각각 67.0 $68.4 \%, 22.127 .9 \%$ 로 계산되었다. 그리고 $\mathrm{Cd}$ 의 기여율은 5.0 $9.9 \%$ 로 나타났다. 봉광산과 비교하여 대정광산에서 $\mathrm{Pb}$ 의 $\mathrm{HQ}$ 가 Cd보다 크게 나타난 것은 Table 6에서 보는 바와 같 이 $\mathrm{Pb}$ 의 지하수노출농도 $(\mathrm{Cw})$ 가 봉광산에서는 산정되지 않 지만 대정광산에서는 상대적으로 높은 수준이기 때문에 그 에 따라서 Table 8에 제시된 것처럼 지하수섭취경로에 대한 노출량이 증가했기 때문인 것으로 판단된다.

두 광산별 발암 및 비발암위해도를 비교해 보면, 먼저 발 암위해도 경우, 두 광산의 각 수용체별 TCR이 큰 차이를 보 이지 않기 때문에 두 광산에서의 발암위해성은 유사할 것 으로 판단된다(Table 9). 그리고 비발암위해도를 나타내는 $\mathrm{HI}$ 를 살펴보면 큰 차이는 없지만 다소나마 봉광산보다 대 정광산에서 크게 나타나 대정광산의 비발암위해성이 상대 적으로 큰 것으로 판단된다.

특이할 만한 사항은 Table 10에 제시된 발암 및 비발암위 해도에 대한 노출경로별 기여도를 수용체별로 비교하였을 때, 어린이의 경우에는 성인남성과 성인여성에 비해 상대적 으로 표토섭취 및 표토피부접촉의 기여율이 다른 노출경로 에 비해서 크다는 사실이다. 먼저 발암위해도에서 두 경로 별 기여도를 살펴보면, 표토섭취경로의 경우, 봉광산에서 어 린이 $(0.9 \%)>$ 성인여성 $(0.3 \%) \approx$ 성인남성 $(0.3 \%)$, 대정광산 에서 어린이 $(1.1 \%)>$ 성인여성 $(0.4 \%) \approx$ 성인남성 $(0.4 \%)$ 로 나 타났다. 그리고 표토피부접촉경로의 경우를 비교해보면, 봉 광산에서 어린이 $(5.8 \%)>$ 성인여성 $(2.4 \%) \approx$ 성인남성 $(2.2 \%)$, 대정광산에서 어린이 $(7.1 \%)>$ 성인여성 $(3.0 \%) \approx$ 성인남성 $(3.0 \%)$ 로 계산되었다. 비발암위해도의 경우도 살펴보면, 먼 저 표토섭취경로의 경우, 봉광산에서 어린이 $(0.8 \%)>$ 성인여 성 $(0.3 \%) \approx$ 성인남성 $(0.3 \%)$, 대정광산에서 어린이 $(0.8 \%)>$ 성인여성 $(0.3 \%) \approx$ 성인남성 $(0.3 \%)$ 로 나타났다. 또한 표토피 부접촉경로의 경우를 비교해보면, 봉광산에서 어린이(14.5\%)> 성인여성 $(6.2 \%)>$ 성인남성 $(5.8 \%)$, 대정광산에서 어린이 $(8.4 \%)>$ 성인여성 $(3.4 \%) \approx$ 성인남성(3.2\%)로 계산되었다. 이 두 노출 경로를 제외한 나머지 노출경로에서는 모두 성인남성 및 성 인여성의 기여도가 어린이보다 더 컸다. 어린이인 경우에 이러한 두 노출경로에서 기여율이 상대적으로 크게 나타난 이유는 Table 1에 제시된 노출량 산정식과 Table 2의 수용 체 특성을 반영한 노출인자로부터 유추해 낼 수 있다. 먼저 표토섭취경로를 살펴보면, Table 1의 첫 번째 노출량 산정 식에서 분자에 포함되어 노출량과 정의 상관관계에 있는 표 토섭취량(CRs)을 Table 2에서 검토해 보면 어린이의 값(118) 이 성인남성과 성인여성의 값(50)에 비해서 약 2.4 배 가량 크다. 그리고 두 번째 표토피부접촉경로에 대한 노출량 산 정식의 토양-피부간 흡착계수(AF)를 Table 2에서 수용체별 로 비교해 보면 역시 어린이의 값(0.20)이 성인남성과 성인 여성의 값(0.07)보다 2.8배 크다. 그 외 다른 노출인자는 모 든 노출경로별로 동일하게 적용되기 때문에 결국에는, 이 두 가지 노출인자에 의해서 성인남성과 성인여성에 비해 어린 이의 표토섭취경로와 표토피부접촉경로에 의한 노출량이
증가하게 되고, 이에 따라서 이 두 노출경로의 발암 및 비발 암위해도에 대한 기여율이 커지는 것으로 판단된다.

\section{4. 결 론}

본 연구는 국내 폐금속 광산에 특화된 인체위해성평가 방 법을 제시하고, 두 폐금속 광산 지역에 시범적으로 적용하 여 광산별 중금속 오염물질에 대한 인체위해도를 정량적으 로 산출하고자 수행되었다. 이를 위해 폐금속 광산에 적합 한 노출경로 등의 노출시나리오를 설정하고, 폐금속 광산 지역 거주 주민의 특성에 맞는 노출인자를 추출하여 인체위 해성평가 시 활용하였다. 또한 최종적으로 얻어진 발암 및 비발암 위해특성을 광산별, 노출경로별, 오염물질별, 수용 체별로 비교 분석하였다.

본 연구에서는 $\mathrm{As}, \mathrm{Cd}, \mathrm{Cu}, \mathrm{Pb}, \mathrm{Zn}$ 등 5종의 중금속 오염 물질을 대상으로 하여 토양(표토), 지하수, 지표수(하천수) 등의 환경매질 내 이들 오염물질의 농도를 분석한 후 이로 부터 각 매질별 노출농도를 산정하였다. 오염물질별 노출농 도와 노출량 산정식, 그리고 다양한 노출인자를 이용하여 각 노출경로별 노출량을 결정하였다. 특히, 수용체와 관련 된 노출인자는 폐금속 광산 주변 거주 주민의 특성을 최대 한 반영하기 위하여 5년간 수행된 폐금속 광산 주민건강영 향조사 결과로부터 각 노출인자를 획득하여 사용하였다. 그 리고 각 오염물질별 발암 및 비발암독성치와 계산된 노출 량을 비교하여 발암 및 비발암위해도를 결정하였다.

먼저 광산별 노출량을 비교하면, 노출농도가 두 광산별 노 출량을 좌우한 것으로 판단된다. 노출경로별 노출량은 농작 물섭취와 지하수섭취가 주요한 노출경로로 조사되었으며, 노출농도와 노출인자 모두로부터 영향을 받는 것으로 판단 된다. 중금속 오염물질별 노출량을 비교했을 때 오염물질별 노출량은 노출경로에 따라서 상이하게 나타났고, 오염물질 별 노출량은 노출농도보다는 체내흡수계수 $\left(\mathrm{ABS}_{\mathrm{GI}}\right)$, 피수흡 수계수 $\left(\mathrm{ABS}_{\mathrm{D}}\right)$ 호흡흡수계수 $\left(\mathrm{ABS}_{\mathrm{inh}}\right)$ 등과 같은 노출인자에 더 영향을 받는 것으로 판단된다. 수용체별 노출량을 비교해 보면, 성인남성 > 성인여성>어린이 순으로 높게 나왔으며, 이는 각 수용체별 특성이 반영된 결과로 사료된다.

최종적으로 산출된 발암위해도를 살펴보면 두 광산 모두 에서 총 초과발암위해도가 모든 수용체에 대하여 허용 가 능한 발암위해도인 $1 \times 10^{-6}$ 의 값보다 크게 나타나서 발암위 해성이 있는 것으로 판명되었다. 두 광산별 발암위해도를 비교해 보면, 두 광산의 각 수용체별 총 초과발암위해도가 큰 차이를 보이지 않아 두 광산에서의 발암위해성은 유사 할 것으로 판단된다. 농작물섭취와 지하수섭취에 의한 초과 발암위해도가 다른 노출경로들에 비해 월등히 높게 나타났 는데, 이는 노출경로별 노출량의 차이가 반영된 결과라 생 각된다. 오염물질들 중에서는 $\mathrm{As}$ 의 초과발암위해도가 가장 높게 나타났다. 비발암위해도를 살펴보면, 두 광산 모두에 
서 성인에 대한 위험지수가 1 보다 큰 값을 보여 비발암위해 성이 있는 것으로 나타났고, 어린이의 경우에는 상대적으 로 비발암위해성이 낮은 것으로 조사되었다. 두 광산별 비 발암위해도를 비교해 보면, 큰 차이는 없지만 다소나마 봉 광산보다 대정광산에서 크게 나타나 대정광산의 비발암위 해성이 상대적으로 큰 것으로 판단된다. 노출경로별 비발 암위해도는 발암위해도와 유사하게 농작물섭취와 지하수섭 취에 의한 노출경로에서 높게 나타났다. 그리고 주요한 비 발암위해성 오염물질은 $\mathrm{As}, \mathrm{Cd}, \mathrm{Pb}$ 로 조사되었다. 수용체 별로 살펴보면, 어린이의 경우 표토섭취와 표토피부접촉 경 로에 의한 발암 및 비발암위해성이 큰 것으로 나타났다.

본 연구에서 수행한 폐금속 광산의 중금속오염 인체위해 성평가의 한계점은 $\mathrm{Cu}, \mathrm{Pb}, \mathrm{Zn}$ 과 같이 매질별 노출농도가 존재하더라도 생축적계수, 체내흡수계수 등과 같은 노출인 자의 부재로 인하여 노출량이 산정되지 않은 경우가 있다. 따라서 기본 노출인자 획득을 위한 연구들이 수행되어야 할 것으로 생각된다. 뿐만 아니라 농작물섭취 경로의 경우, 본 연구에서는 표토 노출농도와 생축적계수를 이용하여 노출 량이 산정되었으나, 실제 농작물 내 노출농도를 이용한 노 출량이 도출되어야 할 것으로 판단된다. 그리고 환경부의 토양오염공정시험법 및 토양오염 위해성평가지침에는 전함 량 분석법에 기반한 토양 노출농도를 위해성평가에 이용하 도록 되어 있는데 인체 및 농작물로의 흡수정도를 고려한 분석법에 의한 노출농도를 이용하여 위해성평가가 이루어 지는 것이 바람직할 것으로 사료된다. 따라서 위해성평가를 위한 적절한 분석법의 개발 및 평가가 선행되어야 할 것으 로 판단된다. 본 연구에서 도출된 인체위해성평가 결과는 향후 폐금속 광산의 복원 및 관리 계획 수립을 위한 의사결 정과정에 활용될 것으로 기대된다. 현재는 위해성과 상관없 이 토양오염 우려기준 또는 대책기준 등의 법적 규제치에 근거하여 복원목표를 설정하고 있다. 따라서 이러한 오염 부지의 위해성을 고려하지 않고 복원 및 관리 계획이 수립 됨으로써 불필요한 사회경제적 비용부담이 증가할 수 있으 며, 최종적으로는 복원 후에도 주민건강에 대한 무해화를 보증할 수 없는 결과를 초래할 수 있다. 따라서 위해성에 근 거한 복원 및 관리 계획을 마련할 때 본 연구의 결과가 활 용될 것으로 판단된다.

\section{Acknowledgement}

본 연구는 한국광해관리공단의 광해방지기술개발사업의 지원을 받아 수행되었으며, 이에 감사드립니다.

KSEE

\section{References}

1. Jung, M. C. and Jung, M. Y., "Evaluation and management method of environmental contamination from abandoned metal mines in Korea," J. Korean Soc. Mineral Energy Res., 43(5), 383 394(2006).

2. Ministry of Environment, "Investigation of soil contamination in abandoned mine (chungbuk province),"(2004).

3. Hwang, E. H., Wee, S. M., Lee, P. K. and Choi, S. H., "A study on the heavy metal contamination of paddy soil in the vicinity of the seosung Pb-Zn mine," J. Soil and Groundwater Environ., 5(2), 67 85(2000).

4. US EPA, "Framework for inorganic metals risk assessment (EPA/630/P-04/068),'(2004).

5. An, Y. J., Baek, Y. W., Lee, W. M., Jeong, S. W. and Kim, T. S., "Comparative study of soil risk assessment models used in developed countries," J. Soil Groundwater Environ., 12(1), 53 63(2007).

6. Brand, E., Otte, P. F. and Lijzen, J. P. A., "CSOIL 2000: an exposure model for human risk assessment of soil contamination (A model description) (RIVM report 711701054/ 2007),"(2007).

7. Environmental Agency, "CLEA software (version 1.05) handbook,"(2009).

8. ASTM, "Standard guide for Risk-Based Corrective Action (RBCA),"(2010).

9. Ministry of Environment, "Guidelines for risk assessment of soil contaminants,"(2006).

10. Ministry of Environment, "Investigation of environments of abandoned mines,"(2005).

11. Ministry of Environment, "Investigation of environments of abandoned mines,"(2007).

12. National Institute of Environmental Research (NIER), "Investigation of health effect on inhabitants around abandoned metal mines,"(2007).

13. National Institute of Environmental Research (NIER), "Investigation of health effect on inhabitants around abandoned metal mines,"(2008).

14. National Institute of Environmental Research (NIER), "Investigation of health effect on inhabitants around abandoned metal mines,"(2009).

15. National Institute of Environmental Research (NIER), "Investigation of health effect on inhabitants around abandoned metal mines,"(2010).

16. National Institute of Environmental Research (NIER), "Investigation of health effect on inhabitants around abandoned metal mines,"(2011)

17. Korean Statistical Information Service (KOSIS), "KOSIS 100 indices," http://kosis.kr/nsportalStats/nsportalStats_0102Body. jsp?menuId=6\&NUM=156,(2013).

18. Canadian Council of Ministers of the Environment (CCME), "A protocol for derivation of environmental and human health,"(2006).

19. Lee, J. Y., "A study on the body surface area of Korean adults," Ph.D Thesis, Seoul National University, Korea,(2005).

20. Ministry of Environment, "Korean exposure factor handbook," (2007).

21. US EPA, "Exposure factor handbook,"(1997).

22. US EPA, "Risk assessment guidance for superfund volume 
I : Human health evaluation manual, Part F, Supplemental guidance for inhalation risk assessment,"(2009).

23. NEPC, "Guideline on exposure scenarios and exposure setting, National Environment Protection Council," Adelaide, South Australia,(1999).

24. EA, "CLEA UK Handbook (Draft), Support document for the CLEA UK software Beta Version 1.0," Environmental Agency, Bristol, United Kingdom,(2005).

25. US EPA, "Risk assessment guidance for Superfund Volume I : Human health evaluation manual (Part E, Supplemental guidance for dermal risk assessment),"(2004).
26. Health Canada, "Federal contaminated site risk assessment in Canada. Part I : Guidance on human health preliminary quantitative risk assessment,"(2007).

27. Kim, J. Y., Lee, J. H., Kunhikrishnan, A., Kang, D. W., Kim, M. J., Yoo, J. H., Kim, D. H. and Lee, Y. J., "Transfer factor of heavy metals from agricultural soil to agricultural products," Korean J. Environ. Agric., 31(4), 300 307(2012).

28. US EPA, "Soil screening guidance: Technical background document,"(1996).

29. Ministry of Environment, "Guidelines for risk assessment of soil contaminants,"(2015). 